\title{
MOŻLIWOŚCI ODDZIAŁYWANIA WŁADZ SAMORZĄDOWYCH NA WYDAJNOŚĆ WYBRANYCH KATEGORII ŹRÓDEŁ DOCHODÓW WŁASNYCH NA PRZYKŁADZIE GMIN W POLSCE
}

\author{
Pawel Felis*
}

Streszczenie:

Istniejący w Polsce system zasilania samorządu terytorialnego wymaga zmian, w zakresie dochodów podatkowych zmiany powinny dotyczyć systemu podatków od nieruchomości. Potencjalnym źródłem dodatkowych znacznych dochodów gmin powinien być zreformowany podatek od nieruchomości.

Celem artykułu jest zbadanie możliwości wpływania przez gminy na wielkości dochodów z nieruchomości stanowiących własność innych podmiotów. Przeprowadzone analizy dotyczące roli i miejsca podatków od nieruchomości w systemie dochodów polskich gmin, a także wykorzystania narzędzi władztwa podatkowego dowiodły, że władze lokalne w niewielkim stopniu mogą kształtować konstrukcje podatków od nieruchomości do oddziaływania na wielkość ich wpływów oraz przebieg procesów społeczno-gospodarczych.

Słowa kluczowe: dochody samorządu lokalnego, podatek lokalny, podatek od nieruchomości, władztwo podatkowe.

JEL Class: H71, K34.

\section{WPROWADZENIE}

Rozwój społeczności lokalnych uzależniony jest od poziomu realizowanych zadań, których jednym z wyznaczników są rozmiary wydatkowanych środków finansowych. Podstawowy obowiązek samorządu terytorialnego sprowadza się

\footnotetext{
* Doktor nauk ekonomicznych, Instytut Finansów, SGH Warszawa.
} 
do dostarczania produktów i usług publicznych. Jego działalność powinna nie tylko obejmować zaspokajanie bieżących potrzeb społeczności lokalnych, ale także wspierać rozwój społeczno-gospodarczy. Samorząd terytorialny ma więc do odegrania zasadniczą rolę, którą jest rozwiązywanie konfliktów występujących pomiędzy celami podmiotów działających na terenie gminy, a także właściwa koordynacja ich działalności, czego rezultatem są korzyści dla całego systemu lokalnego. Jednostki samorządu terytorialnego muszą więc posiadać zasoby środków finansowych odpowiednie do skali wykonywanych przez nie zadań publicznych. Istotną ich część - zgodnie z teorią finansów publicznych oraz Europejską Kartą Samorządu Lokalnego - powinny stanowić dochody własne, w odniesieniu do których wspólnoty samorządowe mogłyby realizować własną politykę podatkową. Teoria i praktyka finansów publicznych potwierdza prawidłowość, że wykorzystanie środków publicznych jest tym bardziej efektywne, im dysponenci środków i realizatorzy zadań publicznych są bliżej społeczności, na rzecz której działają [Owsiak 2001: 126]. Do teorii, które dostarczają argumentów za decentralizacją procesu decyzyjnego i silnymi strukturami samorządu lokalnego ze względu na lepszą efektywność, odpowiedzialność, zdolności zarządcze i autonomię decyzyjną można zaliczyć: zasadę decentralizacji rozwiniętą przez W. Oatesa [1969], zasadę adekwatności (odpowiedniości), Ch. Tiebouta [1956] oraz zasady regulacji w ramach ,teorii wyboru publicznego" G. Stiglera [1957].

W każdym systemie dochodów samorządowych trwałe i znaczące miejsce powinny zajmować dochody własne. Wśród dochodów samorządowych istotną rolę odgrywają podatki, stanowiąc ważną kategorię decydującą o zakresie samodzielności finansowej samorządu. W krajach europejskich grupy podatków lokalnych są bardzo różnorodne. Dominują jednak modele, w których jednym z najważniejszych podatków jest podatek od nieruchomości. Głównym elementem różnicującym europejskie systemy opodatkowania nieruchomości jest sposób uregulowania podstawy opodatkowania: oparty na wartości lub na powierzchni nieruchomości. W kilku państwach Europy Środkowej i Wschodniej, w tym w Polsce, są wykorzystywane powierzchniowe systemy opodatkowania nieruchomości. W przypadku naliczania podatków w oparciu o powierzchnię nieruchomości, podstawę opodatkowania stanowi kombinacja powierzchni budynku i areału gruntu ${ }^{1}$. Co istotne, ustalając wysokość podatku według wartości jednostkowej (jednostka powierzchni nieruchomości), na ogół pomija się czynniki mogące mieć wpływ na podstawę opodatkowania, które odzwierciedlałyby lokalizację, uwarunkowania rynkowe oraz jakość nieruchomości. Stąd najczęściej w praktyce stosuję się różnicowanie stawek podatkowych. W zależności od przeznaczenia (powierzchnia mieszkaniowa, działalność gospodarcza) stawki

${ }^{1}$ Podatek stanowi sumę powierzchni działki pomnożonej przez stawkę podatku wymierzonego w przeliczeniu na metr kwadratowy gruntu oraz iloczynu powierzchni budynków i stawki przypadającej na metr kwadratowy budynku. 
podatku od nieruchomości mogą się różnić nawet kilkunastokrotnie. Dynamika ilościowej podstawy opodatkowania jest zdecydowanie niższa niż podatków wartościowych, ponieważ wyrażona w jednostkach fizycznych wielkość podstawy opodatkowania jest wolna od skutków inflacji. Wymusza to więc konieczność wprowadzenia mechanizmu waloryzacyjnego, najczęściej w konstrukcji stawek podatkowych.

Obowiązujący w Polsce powierzchniowy model opodatkowania nieruchomości oznacza w praktyce sztywność podstawy wymiaru podatku, a konsekwencje takiej konstrukcji dotyczą zarówno czynnych, jak i biernych podmiotów opodatkowania. Dlatego też celem artykułu jest - poprzez ukazanie specyfiki powierzchniowego modelu opodatkowania nieruchomości - identyfikacja możliwości oddziaływania władz samorządowych na wydajność wybranych źródeł dochodów własnych gmin w Polsce².

Realizacji tak wyznaczonego celu posłużą badania empiryczne obejmujące udział podatków samorządowych (przede wszystkim podatków od nieruchomości) w dochodach ogółem i w dochodach własnych gmin, a także skutki finansowe wykorzystania przez gminy przekazanego im częściowego władztwa podatkowego, czyli uprawnień w przyznawaniu preferencji podatkowych. Dane do analiz pochodzą z opracowań Ministerstwa Finansów, Głównego Urzędu Statystycznego oraz ankiety przeprowadzonej przez Biuro Analiz Sejmowych Kancelarii Sejmu.

\section{PODATKI W BUDŻETACH GMIN W POLSCE W KONTEKŚCIE WŁADZTWA PODATKOWEGO}

W Polsce od 1999 r. obowiązuje trójstopniowy podział terytorialny kraju, układ gminny rozszerzono i uzupełniono o samorząd wojewódzki i powiatowy. Pomimo tego, że dochody jednostek samorządu terytorialnego (dalej jako JST) są bardzo zróżnicowane swoją strukturą wewnętrzną, to jednak możemy wyróżnić trzy podstawowe pozycje: dochody własne, subwencje ogólne oraz dotacje celowe. Szczególną kategorię stanowią dochody własne. Z punktu widzenia samodzielności wspólnot samorządowych istotna jest jednak ich zawartość, do której ustawodawca zaliczył nie tylko podatki i opłaty lokalne w całości wpływające do JST, dochody związane $\mathrm{z}$ gospodarowaniem majątkiem i inne nie mające większego znaczenia, lecz także dochody uzyskiwane z tytułu udziałów w podatkach stanowiących dochód budżetu państwa (udziały we wpływach z podatków dochodowych: od osób fizycznych - PIT i od osób prawnych - CIT). Gminy korzystają z najbardziej rozbudowanej grupy źródeł dochodów własnych, co w konsekwencji umożliwia oddziaływanie władz samorządowych

\footnotetext{
${ }^{2}$ Podobny cel badawczy sformułowała Poniatowicz [2011]. Inna jest jednak struktura artykułu, przedmiot rozważań, wykorzystany materiał empiryczny oraz końcowe wnioski.
} 
na ich wydajność. Obejmują one dochody z podatków samorządowych, reprezentujących przede wszystkim kategorię opodatkowania majątku w postaci substancji majątkowej (opodatkowanie nieruchomości, czyli podatek od nieruchomości, podatek rolny, podatek leśny; opodatkowanie majątku ruchomego, czyli podatek od środków transportowych) oraz transferu majątku (obrót majątkiem, czyli podatek od czynności cywilnoprawnych; przyrost masy majątkowej, czyli podatek od spadków i darowizn).

Z funkcjonowaniem podatków stanowiących źródło dochodów gmin wiąże się także zróżnicowany zakres władztwa podatkowego ${ }^{3}$ (rys. 1). Władztwo podatkowe oznacza prawnie określony zakres uprawnień do podejmowania rozstrzygnięć w sprawach podatkowych, czyli np. konstrukcji poszczególnych elementów podatku czy ukształtowania treści stosunku zobowiązaniowego, czyli wydawanie indywidualnych rozstrzygnięć dotyczących umorzenia, rozłożenia na raty, poboru podatków oraz ich egzekucji [Kornberger-Sokołowska 2001: 83]. Znajdujący oparcie w umocowaniu ustawowym określony zakres władztwa podatkowego to jeden z czterech zasadniczych aspektów samodzielności finansowej jednostek samorządu terytorialnego - dochodowa. Pozostałe, które nie stanowią przedmiotu niniejszego artykułu to: proceduralna, wydatkowa oraz kredytowa.

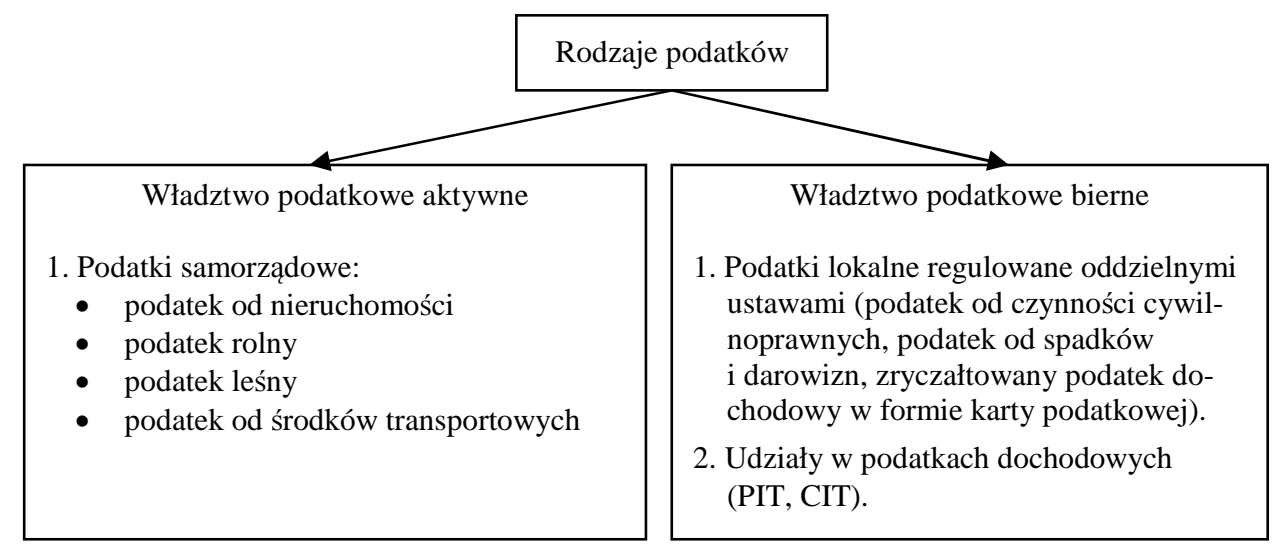

Rysunek 1. Podział podatków zasilających budżety gmin ze względu na zakres władztwa podatkowego

Źródło: opracowanie własne.

${ }^{3}$ Władztwo podatkowe aktywne obejmuje: prawo do korygowania (zawężania lub rozszerzania) technicznych elementów podatków (tzw. ograniczona swoboda legislacyjna) oraz prawo podejmowania decyzji w obszarze technicznego wymiaru podatku (tzw. pełna swoboda legislacyjna). Natomiast władztwo bierne oznacza jedynie prawo do przejmowania dochodów osiąganych z tytułu eksploatacji źródeł podatkowych istniejących na terenie samorządu lokalnego. 
W odniesieniu do podatków lokalnych organy samorządu gminnego mają określony ustawą najszerszy zakres władztwa podatkowego, pozwalający na kształtowanie niektórych elementów konstrukcji podatków, jak np. określenie wysokości stawek podatkowych, w granicach ustalonych przez organy państwowe; różnicowanie wysokości stawek podatkowych, na podstawie kryterium o charakterze przedmiotowym; stosowanie preferencji podatkowych, w postaci zwolnień i ulg o charakterze przedmiotowym; stosowanie umorzenia, rozłożenie na raty i odroczenie terminu płatności.

Rada gminy może przyjmować różne strategie określania poziomu stawek podatkowych i wprowadzania preferencji podatkowych [Sokołowski 2004: 347 i nast.]. Oczywiste jest, że prowadzona przez gminy polityka kształtowania - w ramach posiadanych uprawnień - konstrukcji podatków wpływa na możliwe do pozyskania dochody, zarówno $\mathrm{z}$ omawianych podatków, jak i w pewnym stopniu z innych (np. wpływy z udziału w PIT i CIT), wyznaczających własny potencjał dochodowy jednostek samorządu terytorialnego.

Realizacja strategii polegającej na przyjęciu niskich stawek podatkowych oraz stosowaniu szerokiego wachlarza preferencji podatkowych w krótkim czasie na pewno nie przyniesie korzyści budżetom lokalnym. Warto zwrócić uwagę, że mogą to być skuteczne narzędzia oddziaływania na rozwój przedsiębiorczości (mobilizacja kapitału inwestycyjnego, zwiększenie zatrudnienia). Stąd też motywacje ze strony władz lokalnych mogą wpływać na decyzje dotyczące miejsca prowadzenia działalności gospodarczej. Pozytywne skutki dla gmin w perspektywie długoterminowej, czyli wzrost dochodów budżetowych, mogą zostać osiągnięte poprzez rozwój „lokalizacji czynnej” (napływ nowych, dopiero co powstałych podmiotów gospodarczych) oraz „lokalizacji biernej” (zwiększenie skali działalności podmiotów gospodarczych już istniejących). Nie pozostaje to zatem bez znaczenia dla realizujących działalność przedsiębiorców, a także lokalnej bazy podatkowej. Skala wykorzystywania instrumentów lokalnej polityki jest zróżnicowana w poszczególnych jednostkach samorządu terytorialnego, w zależności od typu gminy (gmina miejska, wiejska), sytuacji finansowej gmin, skali realizowanych zadań, i - co istotne - sposobu postrzegania podatku (tylko przez pryzmat jego funkcji fiskalnej, czy również pozostałych, pozafiskalnych) [Felis 2012: 65 i nast.].

\section{POWIERZCHNIOWY MODEL OPODATKOWANIA NIERUCHOMOŚCI W SYSTEMIE ZASILANIA FINANSOWEGO SAMORZĄDU GMINNEGO W POLSCE}

Największym i najważniejszym źródłem dochodów własnych gmin wśród podatków samorządowych jest podatek od nieruchomości. Podkreślmy jednak, że problem opodatkowania nieruchomości w Polsce - mimo marginalnej wagi finansowej pozostałych podatków majątkowych - należy rozpatrywać nie tylko 
z punktu widzenia samego podatku od nieruchomości, ale także podatków: rolnego oraz leśnego. Obecna formuła opodatkowania nieruchomości ma charakter ekstensywny, ponieważ podstawę opodatkowania stanowi w większości powierzchnia nieruchomości. I tak, w podatku od nieruchomości podstawa opodatkowania jest zróżnicowana $\mathrm{w}$ zależności od przedmiotu opodatkowania. W przypadku gruntów jest nią powierzchnia, w odniesieniu do budynków i ich części powierzchnia użytkowa, a dla budowli ich wartość odtworzeniowa. $\mathrm{W}$ podatku rolnym podstawę opodatkowania dla gruntów gospodarstw rolnych stanowi liczba hektarów przeliczeniowych ustalona na podstawie powierzchni, rodzajów i klas użytków rolnych, wynikająca z ewidencji gruntów i budynków oraz zaliczenia gminy do danego okręgu podatkowego. Natomiast dla pozostałych gruntów rolnych jest to liczba hektarów wynikająca $\mathrm{z}$ ewidencji gruntów i budynków. $Z$ kolei w przypadku podatku leśnego, podstawą opodatkowania jest powierzchnia lasu wyrażona w hektarach, wynikająca $\mathrm{z}$ ewidencji gruntów i budynków. Stawki podatkowe mają dla poszczególnych przedmiotów opodatkowania - z wyjątkiem budowli w podatku od nieruchomości - charakter kwotowy.

Jednym z czynników decydującym o wysokości wpływów z podatku od nieruchomości jest ustalenie właściwego poziomu stawek podatkowych. Realne władztwo podatkowe samorządu terytorialnego realizuje się obecnie głównie poprzez uprawnienie do ustalania wysokości - w granicach określonych ustawowo - stawek opodatkowania. Uwzględniając poszczególne rodzaje przedmiotów opodatkowania, rady gmin mogą także różnicować wysokość stawek stosując $\mathrm{w}$ szczególności określone kryteria, np. w przypadku budynków lub ich części związanych z prowadzeniem działalności gospodarczej - lokalizację, sposób wykorzystywania, rodzaj zabudowy, stan techniczny oraz wiek budynków, a także rodzaj prowadzonej działalności.

$\mathrm{Z}$ punktu widzenia samorządów gminnych istotna jest wydajność fiskalna wpływów podatkowych. Dane o dochodach budżetowych gmin, w tym o dochodach własnych oraz dochodach podatkowych w latach 2008-2012 przedstawiono w tab. 1. Można zauważyć, że dochody budżetowe ogółem w cenach bieżących wzrosły w badanym okresie o $25 \%$, podczas gdy dochody własne i dochody podatkowe wzrosły wówczas odpowiednio o $13,6 \%$ i 11,6\%. Na obserwowany wyższy wzrost dochodów ogółem niż dochodów własnych najważniejszy wpływ mają transfery z budżetu państwa (system subwencjonowania i dotowania samorządów gminnych) oraz transfery pochodzące z UE, a także mechanizm powiązania koniunktury gospodarczej kraju z wielkością dochodów gmin, poprzez zapewnienie im udziałów we wpływach z podatku PIT oraz CIT. Otóż zmniejszeniu udziału dochodów własnych w dochodach ogółem gmin towarzyszył znaczny wzrost udziałów transferów z budżetu państwa oraz dochodów ze źródeł opartych na środkach unijnych. Dochody własne gmin są zdominowane przez dochody podatkowe, przede wszystkim te, z którymi jest związane bierne władztwo podatkowe. 

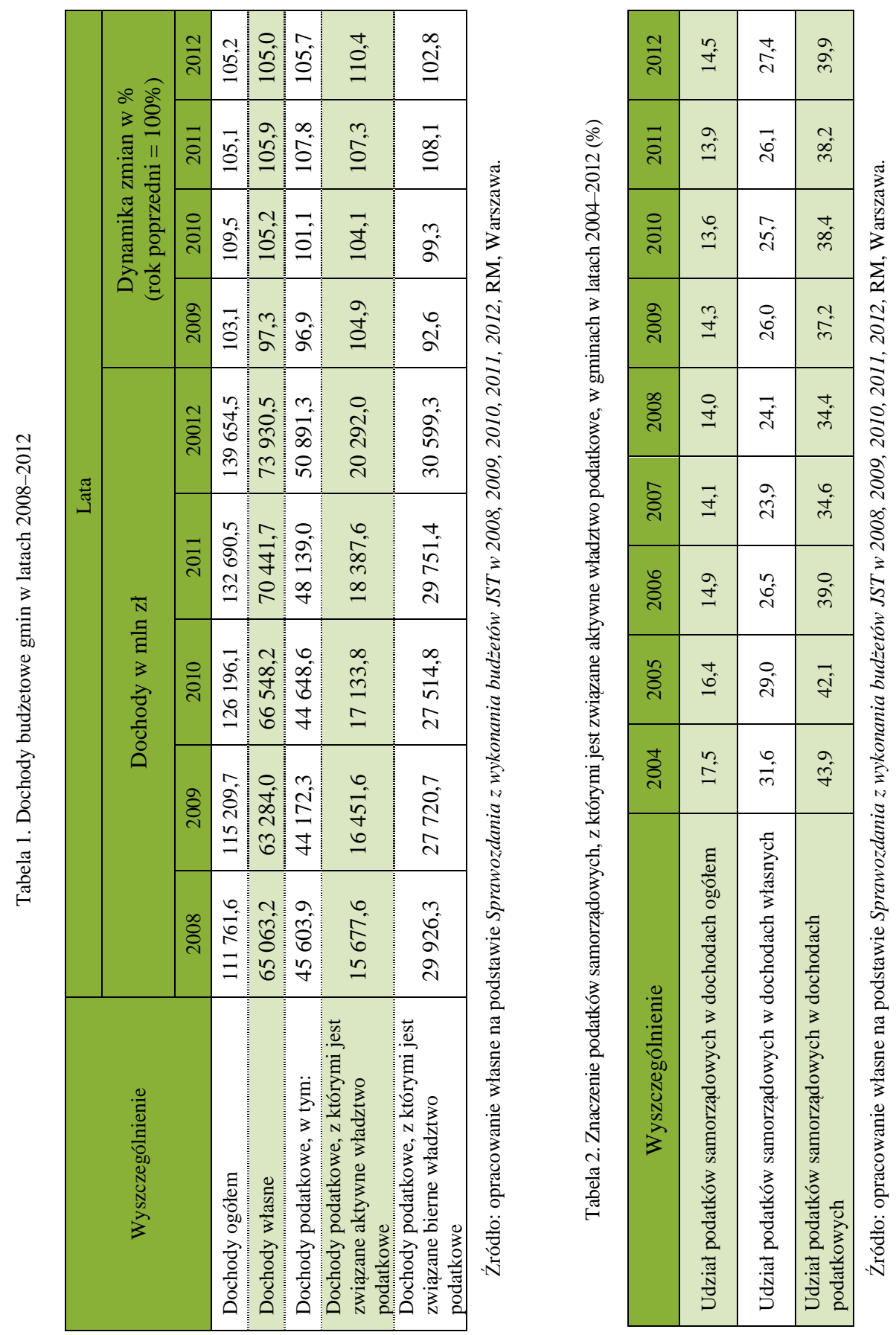
Dochody z tytułu udziału gmin w podatkach centralnych są silnie zdeterminowane przez czynniki makroekonomiczne, a także obciążone cechą ograniczonych możliwości oddziaływania jednostek samorządowych w zakresie kształtowania wydajności tych źródeł. W warunkach pogłębiającego się kryzysu ekonomicznego - w przypadku zdecydowanej dominacji tych dochodów w ogólnej strukturze dochodów własnych gmin - pogarsza się sytuacja finansowa gmin. W analizowanym okresie odnotowano właśnie spadek albo niewielki nominalny wzrost dochodów gmin z tytułu udziału w podatkach państwowych, co było konsekwencją pogorszenia rentowności przedsiębiorstw, obniżenia tempa wzrostu wynagrodzeń oraz ograniczeniem zatrudnienia. Na uwagę zasługuje to, że dochody podatkowe, z którymi jest związane aktywne władztwo podatkowe rosły znacznie szybciej niż pozostałe (wzrost o 29,4\%). Wynikało to $\mathrm{m}$. in. $\mathrm{z}$ tego, że dochody osiągane $\mathrm{z}$ tytułu podatków majątkowych w mniejszym stopniu reagowały na zmiany koniunktury gospodarczej niż będące tzw. automatycznymi stabilizatorami koniunktury podatki dochodowe. Odnosząc się więc do wpływów z podatków od nieruchomości, można stwierdzić, że ich zmiany na ogół różniły się od tendencji wpływów z dochodów ogólnych, własnych oraz pozostałych dochodów podatkowych. Analiza danych nie daje więc podstaw do stwierdzenia, że na przykład w przypadku podatku od nieruchomości doszło do radykalnej zmiany jego poziomu wskutek zmian przebiegu koniunktury gospodarczej. Były one raczej wynikiem przyjętego przez ustawodawcę mechanizmu waloryzacji, który nie oddawał we właściwy sposób rzeczywistych zmian cen na rynku nieruchomości, oraz rodzaju prowadzonej przez gminy polityki podatkowej.

Z zaprezentowanych w tab. 2 statystycznych mierników autonomii finansów gmin i ich niezależności finansowej wynika, że w badanym okresie zmniejszyło się znaczenie podatków samorządowych (podatków majątkowych) w systemie zasilania finansowego samorządu gminnego. Oczywiście podatki majątkowe to tylko jeden z komponentów systemów finansowych gmin, ale nie powinno być wątpliwości, że mamy do czynienia - ze względu na koncepcję podziału podatków na państwowe i samorządowe - z istotną kategorią źródeł dochodów własnych, decydującą o zakresie samodzielności finansowej gmin. Przyjmując zatem, że ich wielkość potraktujemy jako swoisty ,papierek lakmusowy" poziomu samodzielności finansowej gmin, można uznać, iż spadek znaczenia podatków majątkowych jako źródeł dochodów gmin może świadczyć o malejącej ich samodzielności finansowej. Pogorszenie się potencjału dochodowego gmin wynikające z procesu zmniejszającej się wydajności fiskalnej lokalnych źródeł dochodów podatkowych stanowi także poważne zagrożenie dla realizowania zadań i celów społeczno-gospodarczych w systemie gospodarki lokalnej. Od 2008 r. i 2009 r. można zauważyć niewielką poprawę rzeczonych relacji, pozostały one jednak na poziomie znacznie odbiegającym od tego z $2004 \mathrm{r}$. Okazuje się zatem, że podatki majątkowe, traktowane na ogół jako najistotniej- 
sze dochody gmin, świadczące o ich potencjale dochodowym (ponieważ posiadają większość cech uznawanych za pożądane dla podatków lokalnych), nie zawsze stanowią w wystarczającym stopniu stabilną część własnych dochodów gmin. Przytoczone dane wskazują na potrzebę zmian w systemie zasilania finansowego jednostek samorządu terytorialnego w Polsce, przede wszystkim w systemie podatków samorządowych. Mają one bowiem przewagę nad pozostałymi źródłami ze względu na swobodę dysponowania nimi oraz możliwości oddziaływania na ich wielkość.

Wśród podatków samorządowych największe znaczenie fiskalne ma podatek od nieruchomości. Dostarczał on znaczną część środków na realizację zadań publicznych, w badanym okresie jego średni udział w podatkach majątkowych wynosił ponad 87\% (tab. 3). Jego pozycja w budżetach gmin zależy nie tylko od działań władz lokalnych, ale przede wszystkim przyjętych rozwiązań systemowych (system podatku od nieruchomości bazuje głównie na opodatkowaniu powierzchni nieruchomości, ograniczone władztwo podatkowe, znaczne zróżnicowanie opodatkowania nieruchomości w zależności od ich przeznaczenia ${ }^{4}$ ). Pozostałe podatki od nieruchomości (podatek rolny i leśny) należą do mało wydajnych źródeł dochodów gmin. Wysokość wpływów była rezultatem faktu, iż grunty rolne i leśne są obciążone bardzo niskim i pełnym ustawowych preferencji podatkiem rolnym lub leśnym.

Tabela 3. Struktura podatków samorządowych w latach 2008-2012 (\%)

\begin{tabular}{|c|c|c|c|c|c|}
\hline Wyszczególnienie & 2008 & 2009 & 2010 & 2011 & 2012 \\
\hline Podatki samorządowe ogółem & 100 & 100 & 100 & 100 & 100 \\
\hline Podatki od majątku nieruchomego, w tym: & 94,7 & 94,9 & 95,0 & 95,2 & 95,5 \\
\hline - podatek od nieruchomości & 85,8 & 86,3 & 88,2 & 88,4 & 86,8 \\
\hline - podatek rolny & 7,8 & 7,5 & 5,8 & 5,8 & 7,6 \\
\hline - podatek leśny & 1,1 & 1,1 & 1,0 & 1,0 & 1,1 \\
\hline $\begin{array}{l}\text { Podatki od majątku ruchomego } \\
\text { (podatek od środków transportowych) }\end{array}$ & 5,3 & 5,1 & 5,0 & 4,8 & 4,5 \\
\hline
\end{tabular}

Źródło: jak do tab. 1.

Istotnym zagadnieniem w kontekście wykorzystania narzędzi władztwa podatkowego będzie na początku zbadanie ich rezultatów, rozumianych jako efekty budżetowe oraz struktury obniżek dochodów na skutek zmniejszenia stawek i stosowania pozostałych instrumentów. Skomentujmy więc ujęcie kwotowe i procentowe skutków polityki podatkowej gmin w latach 2008-2012 (tab. 4). W badanym okresie łączne skutki finansowe prowadzonej polityki podatkowej

\footnotetext{
${ }^{4}$ Nieruchomości mieszkalne są obciążone w minimalnym stopniu. Natomiast w przypadku gruntów i nieruchomości przeznaczonych na działalność gospodarczą stosuje się bardzo wysokie stawki podatku, co może stanowić, zwłaszcza dla drobnej przedsiębiorczości, poważną barierę w rozwoju.
} 
nominalnie wzrosły o 32,5\%, gminy w większym stopniu wykorzystywały uprawnienia do obniżania stawek (wzrost o ponad 37\%) niż do stosowania pozostałych narzędzi, przede wszystkim o charakterze uznaniowym (wzrost o ponad 19\%). I tak np. w roku 2012 skutki finansowe wykorzystania wszystkich narzędzi w podatkach samorządowych wynosiły prawie 4,4 mld zł, z czego na obniżki stawek przypadało prawie 3,4 mld zł (77\%), a na udzielane ulgi, zwolnienia, umorzenia i odroczenia $1 \mathrm{mld}$ zł (23\%). Finansowy uszczerbek związany z wprowadzonymi obniżkami w podatkach samorządowych charakteryzował się niewielką tendencją wzrostową (od 20,9\% w 2008 r. do 21,5\% w 2012 r.). A zatem, gdyby organy podatkowe nie korzystały ze swego władztwa podatkowego, dochody własne mogłyby być większe średnio o około $21 \%$. W wyniku obniżenia przez rady gmin górnych stawek wysokość utraconych dochodów z podatków samorządowych w latach 2008-2012 stanowiła średnio około 15,5\% wykonanych dochodów, natomiast wykorzystanie pozostałych preferencji podatkowych uszczupliło wpływy średnio o 5,5\%. Ogólne spostrzeżenia na temat relacji między osiąganymi dochodami podatkowymi a skutkami stosowanego przez gminy wsparcia pozwalają na sformułowanie pewnych wniosków. Otóż wartość fiskalnego wsparcia nie stanowi dużego obciążenia dla budżetu gminnego, ich skutki średnio nie przekraczają 3\% dochodów ogółem. Korzystanie przez gminy z narzędzi, których działanie polega na świadomej rezygnacji z części potencjalnych dochodów budżetowych może przyczynić się do pobudzenia aktywności lokalnych przedsiębiorstw i przyciągnięcia inwestorów zewnętrznych. Pozytywnie należy ocenić fakt, że wartość utraconych dochodów z tytułu stosowania niskich stawek podatków samorządowych jest zdecydowanie większa niż wartość utraconych dochodów z tytułu udzielania pozostałych preferencji podatkowych. Świadczy to o tym, że gminy w większym stopniu stosują politykę wsparcia systemowego niż indywidualnego.

Tabela 4. Wykorzystanie narzędzi władztwa podatkowego gmin w latach 2008-2012

\begin{tabular}{|c|c|c|c|c|c|}
\hline Wyszczególnienie & 2008 & 2009 & 2010 & 2011 & 2012 \\
\hline \multicolumn{6}{|c|}{ w mln zł } \\
\hline $\begin{array}{l}\text { Razem preferencje podatkowe } \\
\text { w podatkach samorządowych }\end{array}$ & 3283,5 & 3538,8 & 3579,5 & 3744,4 & 4350,8 \\
\hline Obniżanie górnych stawek podatkowych & 2438,2 & 2569,2 & 2425,2 & 2784,4 & 3342,1 \\
\hline Ulgi i inne & 845,3 & 969,6 & 1154,3 & 960,0 & 1008,7 \\
\hline \multicolumn{6}{|c|}{ w relacji do wpływów z podatków samorządowych w \% } \\
\hline $\begin{array}{l}\text { Razem preferencje podatkowe w podat- } \\
\text { kach samorządowych }\end{array}$ & 20,9 & 21,5 & 20,9 & 20,4 & 21,5 \\
\hline Obniżanie górnych stawek podatkowych & 15,6 & 15,6 & 14,2 & 15,1 & 16,5 \\
\hline Ulgi i inne & 5,4 & 5,9 & 6,7 & 5,3 & 5,0 \\
\hline
\end{tabular}

Źródło: jak do tab. 1. 
W wyniku wykorzystania przez rady gmin możliwości zmniejszania efektywnego opodatkowania w podatku od nieruchomości, wysokość utraconych dochodów nie przekraczała na ogół 1/5 dochodów wykonanych (tab. 5). Wśród stosowanych preferencji w całym okresie dominujące znaczenie miały obniżki stawek podatkowych. Obniżanie górnych stawek podatku stanowiło w badanym okresie średnio ubytek dochodów o $12,4 \%$. Obserwując znaczenie pozostałych instrumentów władztwa podatkowego, należy zauważyć, że w podatku od nieruchomości istnieje dużo przedmiotowych zwolnień ustawowych i prawdopodobnie dlatego gminy nie decydowały się na stosowanie kolejnych. A zatem wartość fiskalnego wsparcia nie stanowi dużego obciążenia dla budżetu gminnego, ponieważ skutki udzielanych ulg i zwolnień średnio nieznacznie przekroczyły $6 \%$ dochodów ogółem z podatku od nieruchomości. Uzupełniając spostrzeżenia na temat dochodów osiąganych $\mathrm{z}$ tytułu podatku od nieruchomości przez gminy, należy stwierdzić, że ich dynamika wzrostowa (2009 r. - 105,5\%, 2010 r. - 106,6\%, 2011 r. - 107,5\%, 2012 r. - 108,3\%) była rezultatem wpływu zarówno czynników egzogenicznych (konstrukcja podstawy opodatkowania oparta na powierzchni nieruchomości, sposób aktualizacji stawek maksymalnych), jak i endogenicznych (sposób prowadzenia polityki dochodowej gmin). Koncentrując uwagę na czynnikach wewnętrznych uważam, że ze względu na wielokierunkowy zakres oddziaływania narzędzi podatkowych, trudno jest jednoznacznie ocenić ich skuteczność. Tym bardziej, że stymulacyjna funkcja podatków samorządowych wymaga właściwej korelacji pomiędzy lokalną polityką podatkową a polityką państwa w zakresie podatków. Dlatego też uważam, że większe znaczenie należy przypisać polityce podatkowej gmin o nastawieniu fiskalnym, polegającej na systematycznym podwyższaniu stawek podatkowych do poziomu zbliżonego do maksymalnego, ze względu na niekorzystne wahania koniunktury gospodarczej i konieczność poszukiwania dodatkowych dochodów budżetowych.

Tabela 5. Skutki finansowe wykorzystania narzędzi władztwa podatkowego w podatku od nieruchomości w latach 2008-2012 (w mln zł)

\begin{tabular}{|c|c|c|c|c|c|}
\hline \multicolumn{1}{|c|}{ Wyszczególnienie } & 2008 & 2009 & 2010 & 2011 & 2012 \\
\hline Wpływy z podatku od nieruchomości & 13447,4 & 14190,0 & 15122,1 & 16253,1 & 17602,7 \\
\hline Kwota utraconych dochodów, w tym: & 2357,5 & 2630,4 & 3048,5 & 3124,6 & 3069,1 \\
\hline \begin{tabular}{c} 
- obniżenie górnych stawek \\
\hdashline- ulgi inne
\end{tabular} & 1569,1 & 1713,1 & 1938,3 & 2199,7 & 2100,8 \\
\hline $\begin{array}{l}\text { Utracone dochody/dochody } \\
\text { z podatku od nieruchomości }\end{array}$ & 788,4 & 917,3 & 1110,2 & 924,9 & 968,3 \\
\hline
\end{tabular}

Źródło: jak do tab. 1. 
Interesujące wydaje się także zbadanie zależności między skłonnością gmin do stosowania instrumentów polityki podatkowej a rodzajem gminy. Finansowe skutki podejmowanych decyzji podatkowych w podatku od nieruchomości w zależności od typu gminy zaprezentowano na rys. 2 - widoczne jest wyraźne zróżnicowanie. W gminach mających status miasta na prawach powiatu posiadane władztwo podatkowe wykorzystywane jest w znacznie mniejszym stopniu niż $\mathrm{w}$ pozostałych rodzajach gmin. W jednostkach tych wartość udzielonego wsparcia ogółem w 2012 r. nie przekroczyła 7\% wpływów z podatku od nieruchomości. W odróżnieniu od miast na prawach powiatu, w pozostałych gminach skutki obniżenia górnych stawek oraz udzielanych ulg i zwolnień przekraczały poziom dwucyfrowy (w gminach wiejskich nawet ponad 30\%). A zatem w dużych miastach, dysponujących pokaźną bazą podatkową (typu mieszkaniowego, handlowego, przemysłowego), skutki decyzji podatkowych miały zdecydowanie mniejsze znaczenie niż w pozostałych gminach. Wskazując przyczyny widocznego zróżnicowania polityki podatkowej gmin warto powołać się na niektóre badania [zob. np. Swaniewicz 1996], z których wynika, że małych gminach (o charakterze wiejskim lub miejsko-wiejskim), aktywna polityka podatkowa może być wynikiem silnej bezpośredniej presji społeczności lokalnych, oczekujących niższego opodatkowania. Przedstawiciele rad gmin mogą w ten sposób przypodobać się wyborcom $\mathrm{w}$ przypadku rywalizacji $\mathrm{w}$ walce o władzę $\mathrm{w}$ gminie. W ośrodkach miejskich, charakteryzujących się większą anonimowością relacji władza-obywatel, w których frekwencja wyborcza jest wyższa, czynniki te nie odgrywają już takiej roli. Uważam jednak, że nie powinno się pomijać wpływu takich czynników, jak: aktywność, kreatywność i kompetencje lokalnych decydentów.

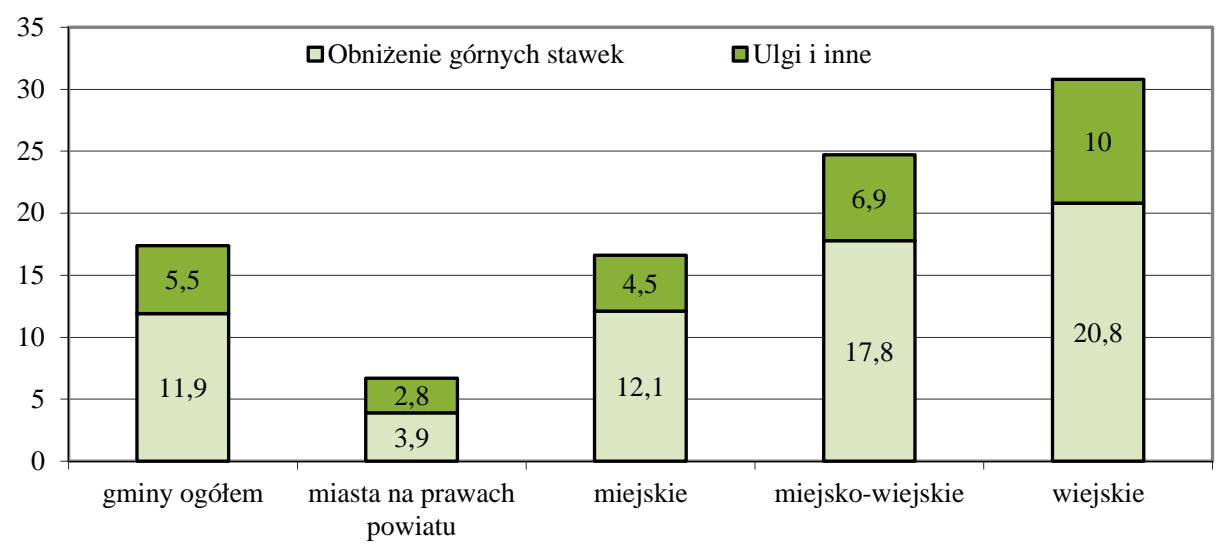

Rysunek 2. Relacje finansowych skutków zastosowania narzędzi władztwa podatkowego do dochodów gmin z tytułu podatku od nieruchomości wg rodzaju gminy w 2012 r. (\%)

Źródło: opracowanie własne na podstawie Sprawozdania z wykonania budżetów JST w 2008, 2009, 2010, 2011, 2012, RM, Warszawa. 
Ponieważ w Polsce największe wpływy z podatku od nieruchomości pochodzą z opodatkowania gruntów i budynków związanych z prowadzeniem działalności gospodarczej, w ostatnim etapie badania zwrócono uwagę na wysokość stawek w podatku od nieruchomości właśnie w odniesieniu do przedmiotów opodatkowania związanych z prowadzeniem działalności gospodarczej. Z raportu przygotowanego przez Biuro Analiz Sejmowych [Gołębiowski i Korolewska (red.) 2013] wynika, że zdecydowana większość respondentów (96\%), którzy odpowiedzieli na pytanie dotyczące stosowania dla prowadzących działalność gospodarczą stawki podatku niższej od maksymalnej, stosowała niższe niż maksymalne stawki podatku od nieruchomości. W przypadku miast na prawach powiatu było to $89,3 \%$, gmin miejskich $93,5 \%$, gmin wiejskich $96,1 \%$, gmin miejsko-wiejskich 97,9\%. W latach 2007-2012 ustawowa stawka podatku od nieruchomości w zakresie podatku od budynków charakteryzowała się stałym wzrostem poziomu maksymalnego (od 18,6 do 21,94 zł za m2). Faktyczne stawki podatku JST biorących udział w badaniu wykazywały także wzrost stawki maksymalnej (od 18,57 do 21,93 zł za $\mathrm{m} 2$ ), lecz na nieco niższym poziomie niż ustawowy. Przeciętna faktycznie stosowana stawka podatku od nieruchomości w badanych JST (liczona za pomocą średniej arytmetycznej) wykazała w analizowanym okresie tendencję rosnącą i zawierała się w przedziale od 15,2 do 18,07 zł za m2. Podobne tendencje wystąpiły w przypadku obliczonej mediany (od 15,71 do 18,5 zł za m2), z tym, że była ona nieznacznie wyższa od średniej arytmetycznej. Wskazuje to na asymetryczny rozkład zbiorowości badanej, o asymetrii prawostronnej.

\section{PODSUMOWANIE}

Podatek od nieruchomości jest oceniany - ze względu na dużo pożądanych cech, które powinny charakteryzować podatki lokalne $(\mathrm{m}$. in.: wydajność odpowiednią w stosunku do realizowanych zadań; równomierne rozmieszczenie przestrzenne bazy podatkowej; jednoznaczność terytorialną; trwały związek przestrzenny bazy podatkowej; ,widoczność” podatku; powszechność obciążeń podatkowych [Swianiewicz 2004: 43-46]) - jako ważne źródło finansowania jednostek samorządu terytorialnego. Istotne jest jednak, czy wysokość podatku jest zależna od powierzchni, czy też wartości nieruchomości.

Słabości konstrukcyjne stosowanych w Polsce podatków związanych z nieruchomościami wpływają na ograniczenie nie tylko ich potencjału fiskalnego, ale także przydatności jako instrumentu kształtowania efektywnej polityki przestrzennej i lokalnego rozwoju gospodarczego. Dla gmin zasadniczym problemem wynikającym z ekstensywności systemu opodatkowania nieruchomości jest ograniczenie wzrostu ich dochodów. Analizując skalę dochodów gromadzonych za pośrednictwem podatku od nieruchomości, ocenia się je z reguły jako 
niewystarczające. W konsekwencji ten niedostatecznie wydajny system zasileń przyczynia się do ograniczenia aktywności inwestycyjnej gmin. Funkcjonowanie samorządu terytorialnego wiąże się jednak z realizacją zadań mających na celu stworzenie odpowiednich warunków dla społeczności lokalnych oraz przedsiębiorców. Wskazane jest zatem, by gminy posiadały zasoby środków odpowiednie do skali wykonywanych przez nie zadań publicznych.

W obowiązującym aktualnie anachronicznym, powierzchniowym systemie opodatkowania nieruchomości, czynnikiem przesądzającym o wielkości wpływów jest wysokość przyjętej stawki podatku. Bardzo duża rozpiętość stawek powoduje jednak nieproporcjonalne rozłożenie ciężarów podatkowych. Maksymalne stawki podatku od nieruchomości przeznaczone na cele mieszkaniowe są ponad 31-krotnie (budynki) oraz 2-krotnie (grunty) niższe niż dla nieruchomości przeznaczonych do prowadzenia działalności gospodarczej. Tak wyraźne uprzywilejowanie określonej grupy podatników jest nie do zaakceptowania, powoduje bowiem zmniejszenie poczucia społecznej sprawiedliwości. Nadmierne obciążenie nieruchomości związanych z prowadzeniem działalności gospodarczej, wpływając hamująco na rozwój przedsiębiorczości, jest także niekorzystne dla gospodarki kraju.

Skala wykorzystania nielicznych narzędzi lokalnej polityki podatkowej jest niewielka. Władztwo podatkowe gmin jest jednak znacznie ograniczone i sprowadza się do określenia wysokości stawek w granicach wyznaczonych ustawowo i wprowadzania innych zwolnień niż zawarte w ustawie. Ponadto w warunkach kryzysowych i pogarszającego się potencjału dochodowego, potrzeby finansowe gmin wynikające $\mathrm{z}$ nałożonych zadań są duże.

$\mathrm{Z}$ przeprowadzonych analiz wynika, że w obowiązującym w Polsce powierzchniowym modelu opodatkowania nieruchomości, władze lokalne $\mathrm{w}$ niewielkim stopniu mogą kształtować konstrukcje podatków od nieruchomości do oddziaływania na wielkość ich wpływów oraz przebieg procesów społeczno-gospodarczych. W kontekście podjętych w artykule rozważań uprawniona wydaje się konstatacja o konieczności zmian w systemie podatków samorządowych. Właściwym rozwiązaniem byłoby stworzenie wydajnego podatku od nieruchomości opartego na wartości. Można jednak przypuszczać, że wprowadzenie bardziej wydajnego podatku i pozostawienie bez zmian pozostałych elementów systemu podatkowego będzie skutkowało znacznym fiskalizmem (przede wszystkim dla właścicieli nieruchomości mieszkalnych).Warto podkreślić, że zmiany w którymkolwiek podatku nie mogą abstrahować od całego systemu podatkowego. Oznacza to, że nałożenie podatku od wartości nieruchomości musi iść w parze ze zmniejszeniem fiskalnego obciążenia w ramach innych podatków obciążających osoby fizyczne i prawne. 


\section{BIBLIOGRAFIA}

Felis P., 2012, Elementy teorii $i$ praktyki podatków majątkowych. Poszukiwanie tadu $w$ opodatkowaniu nieruchomości w Polsce z perspektywy przedsiębiorców oraz jednostek samorzadu terytorialnego, $\mathrm{SGH}$, Warszawa.

Gołębiowski G., Korolewska M. (red.), 2013, Wspieranie rozwoju przedsiębiorczości przez jednostki samorzadu terytorialnego w Polsce, Raport z badań, Wydawnictwo Sejmowe, Warszawa.

Kornberger-Sokołowska E., 2001, Decentralizacja finansów publicznych a samodzielność finansowa jednostek samorzadu terytorialnego, Liber, Warszawa.

Oates W., 1969, The Effects of Property Taxes and Local Public Spending on Property Value: An Empirical Study of Tax Capitalization and Tiebant Hypothesis, ,Journal of Political Economy", vol. 77, no. 6.

Owsiak S., 2001, Finanse publiczne. Teoria i praktyka, Wydawnictwo Naukowe PWN, Warszawa. Patrzałek L., 2004, Finanse samorzqdu terytorialnego, Akademia Ekonomiczna, Wrocław.

Poniatowicz M., 2011, Nieruchomość jako źródto dochodów własnych gminy z uwzględnieniem możliwości oddziaływania władz samorzqdowych na ich wielkość, [w:] L. Patrzałek (red.), Finanse - nowe wyzwania teorii i praktyki. Finanse publiczne, Wydawnictwo Uniwersytetu Ekonomicznego we Wrocławiu, Wrocław.

Sokołowski J., 2004, Czynniki ksztattujace dochody gmin z podatków i opłat, [w:] S. Owsiak (red.), Nauki finansowe wobec wspótczesnych problemów gospodarki polskiej. Tom 1. Finanse publiczne, Akademia Ekonomiczna, Kraków.

Sprawozdanie z wykonania budżetów JST w 2004, 2005, 2006, 2007, 2008, 2009, 2010, 2011, 2012, RM, Warszawa.

Stigler G., 1957, The Tenable Range of Functions of Local Government, [w:] Joint Economic Committee, Federal Expendditures Policy for Economic Growth and Stability, Washington, DC.

Swianiewicz P, 2004, Finanse lokalne, teoria i praktyka, Municypium, Warszawa.

Swianiewicz P., 1996, Zróżnicowanie polityk finansowych władz lokalnych, „Transformacja Gospodarki”, nr 73, Instytut Badań nad Gospodarką Rynkową, Warszawa.

Tiebout C., 1956, A pure theory of local expenditures, „Journal of Political Economy”, vol. 64, no. 5 .

\section{THE IMPACT OF LOCAL GOVERNMENTS ON THE EFFECTIVENESS OF SELECTED OWN REVENUE SOURCES AS EXEMPLIFIED BY COMMUNES IN POLAND}

The current system of funding local self-governments in Poland requires changes; within tax revenues the changes should concern the system of real property taxes. The reformed real property tax should be a potential source of considerable additional commune revenues.

The article is aimed at the analysis of how communes can affect the volume of revenues from real property owned by other entities. The analyses concerning the role and place of real property taxes in the system of revenues of Polish communes and the application of tax authority tools indicate that local authorities can develop to a slight degree the structure of real property taxes to affect the volume of their revenues and the course of social and economic processes.

Key words: local government revenue, local tax, property tax, tax authority. 